Marlena Wanda Stradomska

Maria Curie-Sklodowska University

in Lublin, Poland

\title{
EMOTIONAL CONTROL AND BURNOUT IN SPORTSMEN ON THE EXAMPLE OF FOOTBALL PLAYERS
}

\begin{abstract}
This research paper is the conclusion of the considerations that have emerged as a result of research conducted since 2018. The relationships related to the control of emotions and professional burnout in athletes were investigated on the example of footballers. The study involved men in the age of emerging adulthood (19-30 years old), most of them come from the areas of eastern Poland. Ultimately, the responses of 420 men were taken into account. This work is both theoretical and practical, due to the practical implications added to the article. The research results may contribute to the discussion on the definition and functioning of people professionally involved in sport. This issue still insufficiently remains within the scope of research interests of social sciences. In order to obtain data on the planned research, an author's questionnaire, Maslach Burnout Inventory (MBI), CECS Emotional Control Questionnaire by M. Watson and S. Greer, scale adapted by Z. Juszczyński was used. Additionally, the second part of the study was conducted in the form of structured interviews in order to obtain more detailed information. The most important relationships identified on the basis of this study: the higher the level of subjectively perceive demotional control in athletes on the example of footballers, the greater the sense of professional achievement and the lower the sense of emotional exhaustion and depersonalization. Another important issue is that people involved in sports professionally (for morethan 5 years) significantly more often perceive the work of an athlete as possibly burnout professionally. The reasonsinclude the lack of newachievements in sport and notice able physical deficits. These result sare just the beginning of the debate on subjects related to the issue of burnout and emotional control in athletes.
\end{abstract}


It is necessary to pay attention to psychological issues in athletes on the example of soccer players. Large differences can be seen in the context of participation in a sports club. The more the club is financed, the more additional activities are offered to athletes. Important issues for the respondents, which results from structured interviews, are biological regeneration, contact with a trainer, a group of colleagues, a psychologist or paying attention to coping with stress, experiencing failures or injuries. Also important is the possibility of career advancement, raise the prestige of theirwork and appreciation.

KEYWORDS: emotional control, burnout, professional athletes, psychological help, football players

\section{INTRODUCTION}

Sport and physical culture constitute an interesting area of analysis both in terms of theoretical achievements and the results of specific research. An athlete who takes up professional activity in this area is undoubtedly exposed to the appearance of injuries and physical injuries (Gustafsson, Madigan, Lundkvist, 2018). However, it is worth while, apart from physical injuries, to pay attention to the human mental sphere. The appearance of the listed onescan cause many negative consequences, which may contribute to the fact that an active person loses both physical and psychological resources. The subjectrelated to physicalrehabilitation in Poland began to develop in the 1960s. Doctors, psychologists and kinesio therapists were involved in the development, and with the emergence of other aspects, the activity was expanded (Manilo, 2014). Occurrence of contusions or injuries may cause a decrease in a person's level of motivation, and even the idea of givingup a sports career appears. In addition to the afore mentioned, athletes are exposed to fatigue, over training, mental breakdowns and anxiety states. These can result in a loss of pleasure in playing sports (Hadła et. al, 2006; Gümüşdağ, 2013; Hill, Curran, 2016)

The article presents the theoretical basis of the research - the concept of the professional burnout syndrome in sport - mainly related to the phenomenon of occupational burnout. Additionally, in the available literature, one can find many concepts related specifically to burnout in sport, which is indicated by 
a reduced sense of fulfillment as well as the devaluation of sport. Such an approach to the phenomenon allowed to emphasize the important components of the burnout process in such a specific field as sport. The end of a sports career is an inevitable moment in the career of every athlete. Depending on the circumstances, it may be perceived as a positive and planned event but may also be interpreted as an unexpected and unwanted moment (DyrlaMularczyk, 2017).

Football is a sport that requires a variety of skills from athletes (Reilly, 2008). The wide range of activities performed by footballers is conditioned by the high efficiency of the motor system. The motor activities while playing football include: jumping, passing, turns, shots, head bounces (Gustafsson, Madigan, Lundkvist, 2018). These are movements that depend on high precision, coordination, a strong muscular-ligamentous apparatus and high condition. It should be noted that a football player runs a distance of about $5-17 \mathrm{~km}$ during one match (Rogowska, 2020; Rybaczyk, Klimczyk, 2017). Playing football involves a lot of strain on the athlete's body. It is important that the players are properly prepared for such a great effort and demonstrate the reliability of their work tool (Hadła et. al, 2006; Gümüşdağ, 2013; Hill, Curran, 2016).

Additionally, the burnout syndrome corresponds to a certain extent with the phenomenon of routine emerging among athletes. It is important to use preventive measures, e.g. supporting the development of social skills, which can help in a situation of loss of involvement in sports activities, loss of motivation, self-esteem or self-confidence (Czajkowski, 1991).

What is more, it can be said with certainty that football, compared to other contact sports, is characterized by more frequent injuries (Gustafsson, Madigan, Lundkvist, 2018). Football is classified as a sport of moderate to high intensity collisions and contacts that may cause physical difficulties. The largestpercentage of all the damagerelates to practicingsports and football is as high as 60\% (Koutuers, Andrew, 2011; Leininger, Knox, Comstock, 2007).

The Council of Europe, which is an international governmental organization, defines sports injury as a consequence of participation in sports activities, which is associated with reducedability to perform physical activity, the need for medical assistance and economic consequences. An important issue for specialists in many fields is to protect athletes against possible injuries. 
If, however, such difficulties arise, it is important to counteract the negative effects (Altahayneh, 2003; Appleton, Hill, 2012; Caccese, Mayerberg, 1984).

Based on the analysis of the International Football Federation FIFA during the 2002 World Cup, it was shown during the 64 matches that there was 2.7 damage per match. $37 \%$ of injuries were caused by fouls, $36 \%$ were caused by direct contact with another player, and 27\% were injuries that occurred despite no contact with an opponent (Hadła et. al, 2006). According to the CPSC, in 2006 There were 186,544 injuries related to playing football. Where as between 1990 and 2003 in the United States, $1,597,528$ injuries related to football were estimated. These figures may differ due to the fact that many clubs do not report all injuries of their players (Koutuers, Andrew, 2011).

\section{BURNOUT AMONG PROFESSIONAL ATHLETES (FOOTBALLERS)}

Burnout is treated as a dynamic, multi-stage complex of symptoms appearing in three areas: psychological emotional exhaustion, depersonalization and a reduced sense of personal accomplishments (Mularczyk, Bojkowski, 2017). The forerunner of research in the field of occupational burnout, Herbert J. Freudenberger, describes this state as the highest level of weakening of the body's strength, which entails a decline in vitality and motivation to perform everyday professional activities (Sęk, 2004; Sęk, 2000).

Burnout is also manifested in the reduction of motivation, lack of satisfaction is currently reaping the profession (sports), reduced efficiency, mood disorder, predominantly negative emotions, development of a sense of inferiority. In the field of sports, in particular, results in a reduced physical and mental performance (Slimani et. al. 2018; Tomczak et. al. 2013; Uher, Bukova, 2018). Additionally, itis the result of the synergy of physiological, behavioral and cognitive factors of anupset situation (Mularczyk, Bojkowski, 2017). According to the theories of Maslach, Leiterand Raedeke, there are three factors that help to distinguish burnout syndrome from other stressful situations that can happen at work. These include such elements as: emotional weariness, the person has the impression that he cannot control his emotions. Additionally, depression, anhedonia, weakness, pessimism, 
irritability, a sense of emptiness, and excessive impulsiveness may appear in a person's life. An important is sue is also social with drawal, blocking interpersonal contacts, as well as a negative assessment of one's own activity and the results of one's work (Maslach, Leiter, 2011). Moreover, the result of a prolonged state of burnout without support and specialist help may be termination of professional activity and a disturbance of psychological well-being (Rogowska, 2020).

There are many possible causes of burnout in athletes:

- a lasting sense of tension and competition, requiring a strong commitment of resources;

- dependence on the opinions of others;

- excessive amount of work and training time;

- $\quad$ strong external pressure to achieve achievements;

- bad relations within the team;

- $\quad$ physiological exhaustion (trauma);

- impracticable requirements towards oneself;

- material problems (low level of earnings, in the absence of achievements and sponsors);

- no sense of autonomy;

- lack of appropriate responses to the feeling of stress, stage fright and negative emotions;

- $\quad$ lack of resistance to negative feedback;

- player temperament and identity (Devantier, 2011; Gee, Marshall, King, 2010; Goodger et. al. 2021).

Important issue for the success of athletes in addition to the physiological perseverance it is also a psychological perseverance and the ability to control emotions in stressful situations. Other styles of coping with stress by athletes were distinguished (Hillard et. al., 2014). The style focused on emotions concerns the emergence of negative emotions and the fight against stress in this approach consists in activating the emotional sphere. The avoidance-centric style is to withdraw from the problem and shift your attention to other activities. The task-focused style is considered to be the most effective in the field of sport, which is based on active action and finding methods to solve a difficult situation (Jarvis, 2006). 


\section{Purpose}

This research work is to be the conclusion of considerations emerging as a result of research conducted from 2018 to the present. According to the available literature, it turned out that the topic of burnout in athletes is a serious problem. The relationships related to the control of emotions and professional burnout in athletes were investigated on the example of footballers. The group was selected because soccer is a very popular sport. Relevant data was collected from the men in the second part of the research procedure during the structured interviews. The study involved men of emerging adulthood, who are athletes aged 19-30, most of them come from eastern Poland. The research was carried out in sports clubs.

\section{HYPHOTESIS}

$H 1$ there is a relationship between the overall level of emotional control and burnout, and burnout decreases as the sense of control increases. The following assumptions are a refinement, an extension of Hypothesis 1.

- there is a relationship between the general level of emotional control and the sense of success, the general level of emotional control positively correlates with the sense of success, with the increase in the level of emotional control, the sense of success increases;

- there is a relationship between the general level of emotional control and depersonalization, the general level of emotional control negatively correlates with depersonalization, as the level of emotional control increases, the level of depersonalization decreases;

- there is a relationship between the overall level of emotional control and the sense of exhaustion, the overall level of emotional control negatively correlates with exhaustion, and as the level of emotional control increases, the level of exhaustion decreases.

$H 2$ The level of anger control correlates with the level of burnout;

H3 The level of depression control correlates with the level of burnout;

H4 The level of anxiety control correlates with the level of burnout.

The hypotheses $\mathrm{H} 2, \mathrm{H} 3$ and $\mathrm{H} 4$ are the next overarching hypotheses in this research paper. 


\section{Material AND Methods}

In order to obtain answers to the above questions, research methods were used in this work, which will be described in the following part of the article. The methods that were most appropriate to the selected research group were selected in terms of standardization and characteristics.

\section{AUTHOR'S SURVEY}

The author's survey was aimed at examining issues related to sociological, psychological and professional data in the study group. The survey consisted of 21 items and was divided into the three mentioned categories. In addition, the survey indicated whether the athletes had ever experienced a crisis in their professional or personal life.

\section{Maslach Burnout InVENTORY (MBI)}

The author could definitely use questionnaires available only for the sport related aspects. However, this article focuses mainly on the fact that people who play sports may consider this task as a profession due to the amount of time they spend in training, commitment, etc.

The questionnaire is a method of examining the burnout syndrome. The author defines the burnout syndrome as a syndrome of emotional exhaustion, depersonalization and a reduced sense of personal achievement that can occur among people who perform work based on contacts with other people. The questionnaire contains 22 statements describing the psychophysical state of the body related to the work performed. These are closed questions that respondents answer on a six-point scale. The test consists of three subscales, corresponding to the dimensions of occupational burnout distinguished by Christina Maslach: emotional exhaustion (EEX) - 9 statements, depersonalization (DEP) - 5 statements and professional satisfaction -8 statements. The measure of the risk of burnout results from the sum of the affirmative answers on the scale I and II and the negative answers on the scale III. The questionnaire is a Polish adaptation of the American method developed by Christine Maslach. When adapting the scale, four versions were prepared, 
then the competent judges were asked to rank the items according to the criterion of goodness of the test. The basic criteria were: the correctness of the translation and the linguistic correctness. Items with the highest sum of ranks were included in the final scale (Sękowski, Barej, 2019).

\section{CECS (CourtauldEmotional Control Scale) IN THE ADAPTATION OF Z. JUSZCZYŃSKI}

CECS (Courtauld Emotional Control Scale) consists of three subscales, each of which includes seven statements about how anger, depression and anxiety are revealed. It measures the subjective control of anger, anxiety, and depression in difficult situations; is intended for the examination of healthy and sick adults. The CECS scale is a self-report method. The range of scores for each of the three subscales ranges from 7 to 28 points. By summing up the results of all three subscales, the emotional control index is determined, which represents the subjective belief of an individual as to the ability to control their relationships in a situation of experiencing specific negative emotions. The study may be conducted individually or in groups. The respondent determines the frequency of occurrence of the given manner of expressing his emotions on a four-point scale, from "almost never" - 1 point, to "almost always" - 4 points. The average time to complete the scale does not exceed 10 minutes.

\section{STRUCTURED INTERVIEW}

The second part of the study dealt with psychological and sociological issues. There were 10 questions in the interview. The respondents were asked about their professional, social and psychological experiences. Attention was paid to the issue of occupational burnout, negative emotions and difficulties resulting from the profession.

\section{Participants}

The research group consisted of adults: students of secondary schools and universities from the Lubelskie, Mazowieckie and Małopolskie provinces in Poland. 
The participants of the study were a group of professional athletes playing in the first, second, third and fourth league clubs. The study examined 500 people have been, but in the final analysis were 420 qualified people.Part of the respondents did not agree to end the exploitation of the results in this paper.With the final analysis also eliminated a person just starting their career.

\section{PROCEDURE}

The research was conducted anonymously. The time of execution of the set of methods oscillated around 30-45 minutes. Professional athletes participated in the study. The research has been conducted since 2018 until now, due to the specific research group and difficulties in reaching people from a given age group. All respondents received one questionnaire sheet and instructions that allowed them to understand how to perform the task. The respondents were informed about: who is the initiator and person conducting the research and who is responsible for them; what is the purpose of the study. Moreover, the anonymity of people participating in the research was ensured. The participants obtained information on how to find out about the general results of the research (leaving an e-mail address on an additional sheet). At the beginning, the respondents filled in standardized research methods in the form of questionnaires, then they moved to the next stage of the research, i.e. a structured interview, which will not be described in detail in this article. The respondents could ask questions if the issue related to the task being performed was not clear.

\section{Statistical ANALYSIS}

Statistical analyzes were carried out in the SPSS program from 2020. In order to verify the hypotheses, the non-parametric rho Spearman correlation was used because the distribution of results significantly differed from the normal. 


\section{RESULTS}

In summary statistical analyzes carried out all four hypotheses were confirmed. The general level of emotional control negatively correlates with the level of emotional exhaustion $\left(r_{s}=-0,572 ; p<0,001\right)$ and with the level of depersonalization $\left(r_{s}=-0,487 ; p<0,001\right)$. The general level of emotional control positively correlates with the sense of achievement $\left(\mathrm{r}_{\mathrm{s}}=0,733 ; \mathrm{p}<0,001\right)$. Moreover, the higher the level of subjective emotional control, the greater the sense of professional achievement and the lower the sense of emotional exhaustion and depersonalization. Table 1 shows the relationship between the various aspects of occupational burnout and the level of emotional control.

Table 1.

The relationship between individual aspects of burnout and the level of emotional control

\begin{tabular}{|c|c|c|c|}
\hline & $\begin{array}{c}\text { Emotional } \\
\text { exhaustion }\end{array}$ & Depersonalization & $\begin{array}{c}\text { A sense of } \\
\text { achievement }\end{array}$ \\
\hline$r_{s}$ & $-0,572$ & $-0,487$ & 0,733 \\
\hline $\mathrm{P}$ & 0,001 & 0,001 & 0,001 \\
\hline
\end{tabular}

Table 2.

Relationship between individual aspects of burnout and the level of anger control

\begin{tabular}{|c|c|c|c|}
\hline & $\begin{array}{c}\text { Emotional } \\
\text { exhaustion }\end{array}$ & Depersonalization & $\begin{array}{c}\text { A sense of achieve- } \\
\text { ment }\end{array}$ \\
\hline$r_{s}$ & $-0,529$ & $-0,490$ & 0,706 \\
\hline $\mathrm{P}$ & 0,001 & 0,001 & 0,001 \\
\hline
\end{tabular}

Table 3.

Relationship between individual aspects of burnout and the level of depression control

\begin{tabular}{|c|c|c|c|}
\hline & $\begin{array}{c}\text { Emotional } \\
\text { exhaustion }\end{array}$ & Depersonalization & $\begin{array}{c}\text { A sense of } \\
\text { achievement }\end{array}$ \\
\hline$r_{s}$ & $-0,552$ & $-0,493$ & 0,746 \\
\hline $\mathrm{P}$ & 0,001 & 0,001 & 0,001 \\
\hline
\end{tabular}


Table 4.

Relationship between individual aspects of burnout and the level of anxiety control

\begin{tabular}{|c|c|c|c|}
\hline & $\begin{array}{c}\text { Emotional } \\
\text { exhaustion }\end{array}$ & Depersonalization & $\begin{array}{c}\text { A sense of } \\
\text { achievement }\end{array}$ \\
\hline$r_{s}$ & $-0,544$ & $-0,428$ & 0,692 \\
\hline $\mathrm{P}$ & 0,001 & 0,001 & 0,001 \\
\hline
\end{tabular}

The data presented in Table 2 indicate that the level of anger control negatively correlates with the level of emotional exhaustion $\left(r_{s}=-0,529 ; p<0,001\right)$ and the level of depersonalization $\left(r_{s}=-0,490 ; p<0,001\right)$. On the other hand, it positively correlates with the level of the sense of achievement $\left(r_{s}=0,706\right.$; $p<0,001$ ), therefore the higher the level of anger control, the higher the sense of professional achievement. The level of depression control negatively correlates with the level of emotional exhaustion $\left(r_{s}=-0,552 ; p<0,001\right)$ and the level of depersonalization $\left(r_{s}=-0,493 ; p<0,001\right)$. However, it positively correlates with the level of the sense of achievement $\left(r_{s}=0,746 ; p<0,001\right)$. With the increase in depression control, the negative consequences of burnout in the form of emotional exhaustion and observed depersonalization behaviors decrease, and the sense of professional.Fear control negatively correlates with the level of emotional exhaustion $\left(\mathrm{r}_{\mathrm{s}}=-0,544 ; \mathrm{p}<0,001\right)$ and the level of depersonalization $\left(r_{s}=-0,428 ; p<0,001\right)$. On the other hand, it positively correlates with the level of the sense of achievement $\left(r_{s}=0,692 ; p<0,001\right)$. Moreover, anxiety control is associated with an increase in the sense of professional achievements and a decrease in the sense of the negative consequences of burnout: emotional exhaustion and a sense of achievement.In the next stage, a group of athletes who are professional footballers under six months was compared to a group of more experienced ones. The analysis was performed using the student's T-test. It turns out that work experience influences each of the examined variables $(\mathrm{p}<0,001)$. People with a shorter seniority are characterized by a higher sense of emotional exhaustion $\left(\mathrm{t}_{(420)}=8,129 ; \mathrm{p}<0,001\right)$ and depersonalization $\left(\mathrm{t}_{(420)}=6,679 ; \mathrm{p}<0,001\right)$. However, they feel the sense of achievement to a lesser extent $\left(\mathrm{t}_{(420)}=-13,25 ; \mathrm{p}<0,001\right)$ and control emotions at a lower level $\mathrm{t}\left(\mathrm{t}_{(420)}=-25,06 ; \mathrm{p}<0,001\right)$, including: anger $\left(\mathrm{t}_{(420)}=-21,77 ; \mathrm{p}<0,001\right)$ depression $\left(\mathrm{t}_{(420)}=-16,21 ; \mathrm{p}<0,001\right)$ and anxiety $\left(\mathrm{t}_{(420)}=-15,56 ; \mathrm{p}<0,001\right)$. 
Table 5.

The level of intensity of individual variables in the group of athletes with sixmonth and more professional experience

\begin{tabular}{|c|c|c|c|c|}
\hline Exhaustion & $\begin{array}{c}\text { Half a year } \\
\text { period }\end{array}$ & $\begin{array}{c}\text { Morethan half } \\
\text { a year period }\end{array}$ & $\mathbf{t}_{(420)}$ & $\mathbf{P}$ \\
\hline Depersonalization & 15,4 & 19,23 & 8,129 & $<0,001$ \\
\hline $\begin{array}{c}\text { A sense of } \\
\text { achievement }\end{array}$ & 19,44 & 11,65 & 6,679 & $<0,001$ \\
\hline Anger control & 15,62 & 28,52 & $-13,25$ & $<0,001$ \\
\hline $\begin{array}{c}\text { Depression } \\
\text { control }\end{array}$ & 15,77 & 24,07 & $-21,77$ & $<0,001$ \\
\hline Fearcontrol & 17,07 & 24,4 & $-16,21$ & $<0,001$ \\
\hline General control & 48,45 & 71,95 & $-25,06$ & $<0,001$ \\
\hline
\end{tabular}

Table 6.

The level of intensity of particular variables in different age groups

\begin{tabular}{|l|c|c|c|c|c|}
\hline & $\mathbf{1 9 - 2 2}$ & $\mathbf{2 2 - 2 6}$ & $<\mathbf{2 6}$ & $\mathbf{H}_{(2)}$ & $\mathbf{P}$ \\
\hline Exhaustion & 25,03 & 19,02 & 24,46 & 41,62 & $<0,001$ \\
\hline Depersonalization & 14,98 & 12,15 & 13,08 & 16,92 & $<0,001$ \\
\hline $\begin{array}{l}\text { A sense of } \\
\text { achievement }\end{array}$ & 19,96 & 27,42 & 26,62 & 49,56 & $<0,001$ \\
\hline Angercontrol & 16,39 & 23,4 & 19,69 & 53,59 & $<0,001$ \\
\hline Depresioncontrol & 16,67 & 22,72 & 18,92 & 46,28 & $<0,001$ \\
\hline Fearcontrol & 17,57 & 24,04 & 20,77 & 54,32 & $<0,001$ \\
\hline General control & 50,63 & 70,15 & 59,38 & 51 & $<0,001$ \\
\hline
\end{tabular}

Summing up, as can be seen from the above tables included in these analyzes, there are differences in controlling emotions and the sense of burnout in different groups of athletes. 


\section{Discussion}

Mental and occupational burnout increasingly affect people who carry out their professional tasks. Virtually all professions that require interpersonal contact are at risk of burnout. Burnout, and even its first syndromes, may be associated with the fact that the individual will act against the people he works with or undertaking work effort may adversely affect the psychosocial functioning of a given person.

On the basis of the research carried out, it is possible to select elements that can be classified as appropriate work strategies. The important issues include encouraging cooperation, supervision, setting a clear line, and providing support. The first theories on the phenomenon of occupational burnout appeared relatively late, only in the 70s of the last century. Initially, this issue was dealt with primarily by psychologists, but now it is a field that is included in the field of such disciplines as pedagogy, sociology, medicine, and physiotherapy. Gradually, many studies on work overload began to be undertaken, as a result of which numerous theories were developed to discuss this issue (Kim, Gardant, Bosselut, Eys, 2018).

Pines research shows that burnout is more common in young ambitious people. These people approach the profession with deep commitment and energy, and may also make unreasonable demands on their activities (Pines, 1993). Research has been carried out that connects the trainer's business strategy with burnout syndrome. It turns out that people who cooperate with coaches with an autocratic management style more often declared features of burnout (Altahayneh, 2003). Research on burnout among vocational trainers, broken down by gender, shows that women are more likely to experience burnout because they experience high emotional stress more often. The explanation for this is a greater level of sentimentality in women, higher sensitivity and empathy (Price, Weiss, 2000).

Important studies include the research conducted by Smith (1986) also focusing on the type of sporting activity and its impact on the level of occupational burnout. There are confirmations that people who practice competitions that need individual responsibility, such as table tennis or gymnastics, are at risk and report burnout symptoms more often than people 
who play sports in a team (e.g. football, volleyball). The explanation for this is simple, because the people who work in the team share responsibility with the competitors, which reduces the tension and anxiety during the match and when preparing for it. In 2013, research was conducted in Turkey to identify factors of burnout in terms of age, marital status, education level and position in sports. The study was conducted on a group of 554 male soccer players with an average age of 24 years. The method was the use of various questionnaires. The results of the study showed that age (average 24 years) and anxiety related to competition are significant predictors of the appearance of burnout. The surprising result was that the level of aggression is an insignificant predictor of sports burnout (Ingledew, Markland, Sheppard, 2004).

Another research in the field of occupational burnout and gender division is worth citing a Russian study conducted in 2008 by Hryn Elena, with the participation of 190 athletes. The research resulted in the fact that men are more likely to devalue their own achievements than women. It may mean that women assess their abilities more objectively (Гринь, 2009). Women-athletes exhibit occupational burnout more often due to disorders of the emotional sphere (Гринь, 2008).

\section{BURNOUT AND INTERNSHIP}

The Russian researcher Timakova has conducted a series of studies which claim that internship is not a determinant of occupational burnout, and conversely, people who work in the field of sport for a long time have a developed model of coping with stress, and it is with the help of this model that they have been working for so long and achieve success. According to this theory, people with low psychological perseverance who cannot cope with stressful situations end their professional careers very quickly (Hill, Curran, 2016). Other studies emphasize that there is no significant difference in the propensity to burnout depending on seniority, the conclusion was that at different stages of an athlete's career, there are critical factors that can provoke the appearance of burnout (van Rossum, 2009). The study showed that time contributes to occupational burnout. 


\section{BURNOUT AND EMOTIONS}

Murphy S. with researchers studied the influence of increased load during training on the emotional sphere and the level of physical activity of Olympic judo athletes. Researchers increase the level of overall physiological stress over the course of four weeks, and then the level of specialized exercise over the next two weeks. After the first 4 weeks, the researchers did not notice any negative changes in the emotional sphere of the athletes, but after the next 2 weeks there was an increase in anger and anxiety levels. As in the first and in the second case, researchers also noticed a decrease in the level of physiological performance indicators in terms of strength and anaerobic endurance. Hryn's research carried out in Russia in 2008 on what emotions and states correlate positively and negatively with burnout. The conclusion was that the higher the level of self-esteem, propensity and motivation to achieve achievement, the lower the likelihood of burnout. On the other hand, high levels of tension and anxiety, fear of failure and discrepancy between self-esteem and level of ambition lead to signs of burnout (van Rossum, 2009).

\section{EMOTIONAL CONTROL IN SOCCER PLAYERS}

Regarding the above classification of styles of coping with stress, a study was conducted to identify the styles of athletes compared to the general population. This study was conducted in 2016 at the training center of the Lech Poznań Club. The study involved 31 boys, football players, aged on average 17 years. The method was a survey. The results of the study suggest the following conclusions:

- $\quad$ soccer players at a young age were less likely to exhibit emotional-focused coping style compared to people who did not play sports;

- $\quad$ soccer players exhibit a similar intensity of avoidance-oriented style compared to average non-sporting individuals;

- $\quad$ soccer players at a young age more often displayed task-focused style of coping compared to people who did not play sports (Kalinowski, Pietranis, Bugaj, Lachowska, 2017). 
The theory of Hanin and Lazarus emphasizes that every athlete is influenced by a specific category of emotions, such emotions include „anger, fear, happiness, sadness, joy, surprise and interest". In 2017, a study was also conducted in Bydgoszcz by Rybaczek and Klimczyk in to identify emotions experienced by athletes. The study was conducted on 33 players, they were representatives of various sports fields. The research method was an anonymous questionnaire consisting of 26 questions. The survey showed that $100 \%$ of the respondents understand and have knowledge that the emotional state significantly affects success in sport. Moreover, it can be concluded that people who have been in the profession for a long time have developed effective methods of emotional control. Athletes feel the strongest emotional tension a few days, a few hours or a few minutes before the match, and at the very beginning of the match itself, the tension drops completely and a feeling of joy and pride appears. People with a „hard” temperament with little sensitivity and high endurance have the most opportunities for success in sports. Internal motivation is the most important for athletes and has a positive effect on emotional control (Rybaczyk, Klimczyk, 2017). In 2019, Sękowski and Berej conducted a study by employees of the Institute of Psychology of the Catholic University of Lublin on the temperament and emotional sphere of athletes in individual and team disciplines. The study was conducted using the questionnaire method on a group of 180 men, the average age was 24 years. The main results of the study were the following conclusions:

- the temperamental traits of both groups of athletes do not differ significantly and are usually characterized by „high liveliness, low perseverance, above average sensory sensitivity, low emotional reactivity, very high endurance, high and very high activity".

- athletes in team disciplines obtained a higher level of emotional intelligence, compared to individual athletes who obtained a mean score in emotional intelligence.

- team players obtained an average result in terms of understanding and recognition as well as an empathetic approach to the emotions of others, and individual players obtained a low result in this respect (Гринь, 2008). 


\section{Conslusion}

The project is prospective, and the collected data contributed to the emergence of practical implications valuable for aid work from a psychological and medical perspective. Appropriate preparation of people working with professional athletes may contribute to the fact that the individual, even after an injury or experienced emotional difficulties, may return to better functioning in a short time. Regardless of the league level of a given club, players suffer from many different injuries. In order to prevent injuries, complications or recurrences of dysfunction, each competitor should be provided with comprehensive medical care, which will be available and universal, and will keep the competitor in good shape (Caccese, Mayberg, 1984). The most important dependencies identified on the basis of this study: the higher the level of subjective emotional control in athletes on the example of soccer players, the greater the sense of professional achievement and the lower the sense of emotional exhaustion and depersonalization. Another important issue is that people involved in sports professionally (for more than 5 years) significantly more often perceive work as a professional athlete as possibly burnout professionally. The reasons include the lack of new achievements in sport and noticeable physical deficits. These results are only the beginning of considerations related to the subject of burnout in athletes. The trainer should develop greater regularity, routine, discipline and diligence in athletes by increasing motivation for achievement and intrinsic motivation. In addition, team standards should be clearly defined and enforced for all team members. The trainer, in cooperation with a sports psychologist, should use information about the personality of athletes to make selection decisions and to develop individual development plans for individual team members (Гринь, 2009). Based on the own research, analysis of the obtained results and discussion, the following conclusions were formulated: the emotional control factor is important in how professional athletes function. In addition, working time as a professional footballer may contribute to burnout if a person experiences negative issues at work (interpersonal difficulties with other players, the coach or the lack of facilities affecting his mental well-being). This issue does not support previous research. 


\section{HIGHLIGHTS}

- the higher the level of subjectively perceived emotional control in athletes, based on the example of footballers, the greater the sense of professional achievement;

- the higher the level of subjectively perceived emotional control in athletes, based on the example of footballers, the lower the feeling of emotional exhaustion;

- the higher the level of subjectively perceived emotional control in athletes, based on the example of footballers, the lower the sense of depersonalization;

- $\quad$ people involved in sports professionally (for more than 5 years) significantly more often perceive work as a professional athlete as possibly burning out professionally;

- the causes of professional burnout include the lack of new achievements in sport and noticeable physical deficits, lack of financial support in the club, lack of development opportunities, bad relations with players and the coach, and lack of psychological support.

\section{PRACTICAL IMPLICATIONS}

Summarizing and taking into account the above-presented results of own research, one can propose general conclusions useful in psychological practice. It is indicated that:

- inform athletes about the advantages and disadvantages of practicing professional sports,

- $\quad$ work on improving contacts between players, coach and the community related to practicing professional sports,

- provide medical, psychological, physiotherapeutic and other assistance,

- organize meetings, discuss not only achievements, but also behavior, and jointly search for the sources of their causes,

- work on the psychological aspects of working as a professional athlete,

- work in workshops and training courses with athletes,

- plan activities aimed at promoting knowledge about the control of emotions and the importance of this issue in the development of an individual in various life situations, both personal and professional, 
- make efforts to spread knowledge about burnout and ways to prevent it,

- initiate programs aimed at promoting preventive activities in order to prevent negative effects related to professional work,

- inform about the negative consequences of not intervening in a situation where a person is at risk, for example a suicidal risk (Gee, Marshall, King, 2010).

The theoretical and empirical research carried out has brought many important aspects that will contribute to the development of knowledge and the way of working with people practicing sports professionally, based on the example of football players (Gümüşdağ et. al., 2013).

In the future, the author of the text wants to expand the material and research method, due to the fact that there are methods devoted to burnout in sport, such as the Polish version of the Burnout Questionnaire by Raedeke and Smith (2009). 


\section{REFERENCES}

Altahayneh, Z. (2003) The effects of coaches' behaviors and burnout on the satisfaction and burnout athletes. Dissertation. Tallahassee: Florida State University.

Appleton, P.R., Hill, A.P. (2012). Perfectionism and athleteburnout in junior elite athletes: The mediating role of motivation regulations. Journal of Clinical Sport Psychology, 6, s. 129-145.

Caccese, T.M., Mayerberg, C.K. (1984). Gender differences in perceivedburnout of college coaches. J Sport Psychol. 6, s. 279-288.

Czajkowsk,i Z. (1991). Psychologia sprzymierzeńcem trenera. COS, RCM-SzKFiS, Warszawa.

Devantier, C. (2011). Psychological predictors of injury among professional soccer players. Sport SciRev, 20(5-6), s. 5-36. https://doi.org/10.2478/v10237-011-0062-328.

Dyrla-Mularczyk, K. (2017). Wybrane przyczyny nagłego zakończenia kariery sportowca. Rozprawy Naukowe, 59, s. 66-72.

Gee C. J., Marshall J. C., King, J. F. (2010). Should coaches use personality assessments in the talent identification process? A 15 year predictive study on professional hockey players. Int J CoaSci. 4(1), s. 25-34.

Goodger, K., Gorely, T., Lavallee, D., Harwood, Ch. (2021). Burnout in Sport: A Systematic Review. The Sport Psychologist, 2, s. 127-151. https://doi.org/10.1123/tsp.21.2.127

Gümüşdă̆, H., Bastik, C., Yamaner, F., Kartal, A. (2013). Burnout in professional soccer players: The role of aggression and anxiety.

Gustafsson, H., Madigan, D., Lundkvist, E. (2018). Burnout in Athletes., https://doi. org/10.1007/978-3-662-49322-9_24.

Hadła, M., Bieganowski, K., Wierzbowska, C., Tejedor, N., Snela, S. (2006). Urazowość wśród piłkarzy oraz metody pracy zespołu medycznego w wybranych klubach piłkarskich Polski i Hiszpanii. Medycyna Sportowa [Injury among footballers and methods of work of the medical team in selected football clubs in Poland and Spain. Sports Medicine], 22, s. 272-276.

Hill, A. P., Curran, T. (2016). Multidimensional perfectionism and burnout: A meta-analysis. Personality and Social Psychology Review, 20, s. 269-288.

Hilliard, R. C., Brewer, B. W., Cornelius, A. E., Van Raalte, J. L. (2014). Big Five Personality Characteristics and Adherence to clinic-based rehabilitation activitie safter ACL surgery: A prospective analysis. Open Rehabil J., 7, s. 1-5. https://doi.or g/10.2174/1874943701407010001.

Ingledew, D. K, Markland, D., Sheppard K. E. (2004). Personality and self-determination of exercise behaviour. Pers Individ Differ. 36, s. 1921-1932. https://doi. org/10.1016/j.paid.2003.08.021.

Jarvis, M. (2006). Sport Psychology: A student'shandbook. NY: Routledge. https://doi. org/10.4324/9780203965214. 
Kalinowski, P., Pietranis, D., Bugaj, O., Lachowska, K. (2007). Sposoby radzenia sobie ze stresem wśród młodych sportowców zespołowych gier sportowych [Ways of coping with stress among young athletes in team sports games].

Kim, J., Gardant, D., Bosselut, G., Eys, M. (2018). Athletepersonalitycharacteristics and informal role occupancy in interdependent sport teams. Psychol Sport Exerc., 39, s. 193-203.https://doi.org/10.1016/j.psychsport.2018.07.011.

Koutuers, Ch. G., Andrew, J. M. (2011). Urazy u młodych piłkarzy [Injuries in young footballers] Pediatria po dyplomie, 5, s. 22-28.

Leininger, R. E., Knox, C. L., Comstock, R. D. (2007). Epidemiology of 1.6 million pediatric soccer related injuries presenting to United States emergency departments from 1990 to 2003. Am J Sports Med., 35, s. 288-294.

Manilo, Y. (2014). Locomotor activity of professional football referees. Physicaleducation of students., 18(6), s. 37-40. https://doi.org/10.15561/20755279.2014.0607.

Maslach, C., Leiter ,M. P. (2011) Prawda o wypaleniu zawodowym. [The truth about burnout]. Warszawa: PWN.

Mularczyk, K., Bojkowski, L. (2017). Syndrom wypalenia zawodowego w aktywności sportowej, Polski Przeglad Nauk o Zdrowiu[Burnout syndrome in sports activity] 2(51).

Pines, A. M. (1993). Burnout: Anexistential perspective. W: Schaufeli W, MaslachCh, Marek T (red.). Professional burnout. Washington: Taylor and Francis, s. 33-51.

Price, M. S, Weiss, M. R. (2000). Relationships among coach burnout, coach behaviors, and athletes' psychological response. Sport Psychologist. 14, s. 391-409.

Reilly, J. J., Penpraze, V., Hislop, J., Davies, G., Grant, S., Paton, J. Y. (2008). Objective measurement of physicalactivity and sedentary behaviour: review with new data. Archives of Disease in Childhood, 93(7), s. 614-619. https://doi.org/10.1136/ adc.2007.133272.

Rogowska, A. (2020). Personality differences between academic team sport players and physical education under graduate students. Physical education of students. 24(1), s. 55-62. https://doi.org/10.15561/20755279.2020.0107.

Rybaczyk, D., Klimczyk, M. (2017). Procesy emocjonalne towarzyszące zawodnikowi podczas startu w zawodach sportowych oraz ich wpływ [Emotional processes accompanying the competitor during the start in sports competitions and their impact]. Sęk, H. (2004). Wypalenie zawodowe. Przyczyny i zapobieganie. [Burnout. Causes and prevention]. Warszawa: PWN.

Sęk, H. (2000). Wypalenie zawodowe. [Burnout]. Warszawa: PWN.

Sękowski, A., Barej, M. (2019). Temperament i inteligencja emocjonalna sportowców dyscyplin indywidualnych i zespołowych [Temperament and emotional intelligence of individual and team sportsmen], Czasopismo Psychologiczne Psychological Journal, 2019. 
Slimani, M, Bragazzi, NL, Znazen, H, Paravlic, A, Azaiez, F, Tod, D. (2018). Psychosocial predictors and psychological prevention of soccer injuries: A systematicreview and meta-analysis of the literature. Phy sTher Sport., 32, s. 293-300. https://doi.org/10.1016/j. ptsp.2018.05.00629.

Tomczak, M., Bręczewski, G., Sokołowski, M., Kaiser, A., Czernik, U. (2013). Personality traits and stress coping styles in the Polish National Cadet Wrestling Team. Arch Budo., 9(3), s. 161-168.

Uher, I., Bukova, A. (2018). Interrelationship between Exercise and Diseases in young people: Review study. Physical Activity Review, 6, 203-212. https://doi.org/10.16926/ par.2018.06.25.

van Rossum, J. H. A. (2009). Giftedness and talent in sport. In: Shavinina LV, editor. International Handbook on Giftedness. Dordrecht: Springer, s. 751-791. https:// doi.org/10.1007/978-1-4020-6162-2_37.

Гринь, Е. И. (2008). Личностныерегуляторыэмоциональноговыгорания у спортсменов, Вестник КГУ им. Н.А. Некрасова, том 14, s. 163-168.

Гринь, Е. И. (2009). Психологическоевыгорание в спорте:Теоретическиемодели и причиныфеномена, Человек. Сообщество.Управление. №4, s. 68-75. 